\title{
Macrophytes as habitat for fauna
}

\author{
Hartvig Christie $^{1, *}$, Kjell Magnus Norderhaug $^{1}{ }$ Stein Fredriksen $^{2}$
}

\author{
${ }^{1}$ Norwegian Institute for Water Research, Gaustadalleen 21, 0349 Oslo, Norway \\ ${ }^{2}$ Department of Biology, University of Oslo, PO Box 1069 Blindern, 0316 Oslo, Norway
}

\begin{abstract}
Macrophyte systems, including kelp, seaweed and seagrasses, have revealed high diversity and abundance of associated fauna along the Norwegian coast. In the present study, data from a number of recent studies were assembled and supplemented with new data to elucidate the organisation of macrofaunal diversity on macrophytes. The aim was to compare faunal composition on macrophytes of different size, shape, longevity and function. Macrofaunal densities frequently exceed 100000 individuals $\mathrm{m}^{-2}$ in macrophyte beds. Commonly, high densities of amphipods and gastropods are found. The faunal composition depends mainly on habitat architecture at a spatial micro-scale, while faunal abundances depend on habitat size. These 2 patterns are consistent over larger spatial scales. Most faunal species show high mobility and dispersal rates, and they colonize available habitats rapidly. Macrophyte longevity may, in some cases, influence faunal composition. The macrophytes function both as a habitat and as a food source, but the feeding behaviour of the majority of the faunal components prevents the fauna from overgrazing their habitat and thus destroying the primary producer and foundation species of the community. The perennial macrophytes are mainly consumed as particulate organic matter. A high functional redundancy in both plants and animals is most likely important for the stability of the macrophyte system. The stability and diversity of macrophyte systems are found to be threatened in various ways by overgrazing, removal by storms and commercial harvesting, eutrophication and overfishing of top predators, with concurrent challenges for management.
\end{abstract}

KEY WORDS: Macroalgae $\cdot$ Seagrass $\cdot$ Fauna $\cdot$ Diversity $\cdot$ Stability

\section{INTRODUCTION}

Macrophytes are important primary producers along coasts worldwide, serving as habitat or functioning as ecological engineering species. Seaweed, kelp and seagrasses form small patches or larger vegetation beds which support epiphytic algae and animals, as well as a variety of associated mobile animals, including meiofauna, macrofauna and fish. There have been a number of studies on macrophytes as habitats, but they mainly focus on fauna associated with single species of small red algae (e.g. Dommasnes 1969, Norderhaug 2004), seaweeds (Colman 1940, Hagerman 1966, Edgar 1991), kelps (Jones 1971, Moore 1973, 1986, Edwards 1980, Schultze et al. 1990, Christie et al. 2003) or seagrasses (e.g. Nelson, 1980, Baden \& Phil 1984, Edgar 1990, Baden \& Boström 2000). It is unknown whether the same faunal species are associated with all macrophytes in a coastal area, or whether macrophyte systems of high complexity support a higher diversity of fauna than less complex systems. Macrophytes differ in size, architectural structure and longevity. Differences in structural qualities of the habitat may affect its value as a refuge from predators (Martin-Smith 1993) and wave action (Fenwick 1976). Different animals prefer different substrates (Hacker \& Steneck 1990, Norderhaug 2004, Christie et al. 2007), and structural differences between macrophyte communities may affect faunal species composition. All macrophytes provide habitats of limited duration, while most faunal species have a lifespan of approximately 1 yr. Small turf algae may live for some months, and although fucoid, seagrass and kelp beds persist for many years, the turnover time of leaves or laminas may vary from weeks to months. The faunal species composition on macrophytes may thus be affected by macrophyte longevity and faunal colonisation rates. 
In addition to being important habitats for many organisms, macrophytes are important primary producers in coastal ecosystems, and are therefore a potential food resource for the associated animals. Overgrazing sometimes occurs, showing that grazers have the potential to consume their habitat. Most attention has been given to sea urchins grazing seaweeds, kelps and seagrasses (Lawrence 1975, Norderhaug \& Christie 2009). The removal of the habitat-forming species leads to collapse of the ecosystem and a new ecological state (Elner \& Vadas 1990). Thus, it is important for the persistence of the system that the grazers do not overexploit their habitat. On the other hand, a reduction in small grazers may lead to overgrowth by epiphytic algae and cause severe effects on the habitat-forming macrophytes (Moksnes et al. 2008). Both overgrazing and overgrowth by epiphytes are unusual events, and this suggests that self-regulation occurs in healthy macrophyte systems. Important factors for selfregulation may include food supply and predator refuge for grazers, feeding habits of the grazer and predation pressure, and persistence and resilience are expected to be dependent on diversity within the important functional groups (high functional redundancy, Duffy et al. 2001, 2003, Steneck et al. 2002).

A number of macrophyte species have a wide geographical distribution in the northeast Atlantic. Most fucoids, kelps and the seagrass Zostera marina L. are widely distributed from southern Europe to north of the polar circle. The Norwegian coastline, with fjords and islands, equals a distance of 2 times around the equator $(83000 \mathrm{~km})$ and thus contributes to a significant part of the total European shoreline. The Norwegian coastline is dominated by intertidal and subtidal hard bottoms. These comprise substrate for large areas of diverse macroalgal beds from the shore down to 20 to $30 \mathrm{~m}$ depth, altogether estimated to cover an area greater than $10000 \mathrm{~km}^{2}$. Thus, it is important to identify the role of macrophyte beds as habitats for other organisms, and the Norwegian coast provides an opportunity to compare a variety of macrophytes over small and large spatial scales.

Four different functional groups of macrophytes dominate shallow coastal areas in Norway: fucoids, turf algae, kelp and seagrass. Fucoids are perennial, mostly intertidal species that create a 3-dimensional habitat by being upright during high tide. They form dense beds with a canopy height of 0.5 to $1 \mathrm{~m}$ and are structurally uniform. Fucoids provide shelter and moist conditions by covering the rocky shores when the tide is out. Some fucoids, including Fucus serratus L., may dominate the sublittoral zone to depths of 3 to $4 \mathrm{~m}$ (Fredriksen \& Christie 2003). Estimates of primary production of fucoids are in the range 300 to $1300 \mathrm{~g} \mathrm{C} \mathrm{m}^{-2}$ $\mathrm{yr}^{-1}$ (Lüning 1990, Barrón et al. 2003).
Turf algae include a high number of red, green and brown algal species which are common from the littoral zone down to about $30 \mathrm{~m}$ depth. These are either annual algae occurring during the summer (many green and brown filamentous) or perennial species with reduced size during winter (many red algae species). Turf algae are small and may vary structurally from complex to uniform. In southern Norway, large areas of sugar kelp Saccharina latissima (L.) C.E. Lane, C. Mayes, Druehl \& G.W. Saunders beds in protected areas have been replaced by turf algae (Moy et al. 2008).

Kelp beds are large and structurally complex habitats consisting of perennial species. The dominant macrophyte species along the wave-exposed Norwegian coast is the kelp Laminaria hyperborea (Gunn.) Foslie. This species is characterized by having an annual lamina and a perennial stipe and holdfast that may reach an age of more than $20 \mathrm{yr}$ (Sjøtun et al. 1995), while $\sim 10 \mathrm{yr}$ is a more usual longevity. The 1 to $3 \mathrm{~m}$-long stipe is important for a number of associated epiphytic algae that will contribute to the total primary production in such kelp beds. The number of different epiphytic algal species recorded is in the range of 30 to 45 (Jorde 1966, Marstein 1997). Estimates of primary production in kelp forests are in the range of 1200 to $1900 \mathrm{~g} \mathrm{C} \mathrm{m}^{-2} \mathrm{yr}^{-1}$. However, even higher numbers have been suggested (Abdullah \& Fredriksen 2004).

Seagrass beds may last for many years, while seagrass leaves are short-lived. According to Pinnerup (1980), the leaves are renewed several times each summer. Seagrasses are found in shallow bays on sandy or muddy substrate. The dominant bottom type along the Norwegian coast is rocky shore, therefore seagrass beds are scattered within locations where soft bottoms are present. The dominant seagrass in Norway is Zostera marina (eelgrass). Investigations have shown that seagrasses and fucoids may be heavily overgrown by epiphytes (Fredriksen et al. 2005), and about 100 species of epiphytic algae have been found in these systems. Seagrass beds are also considered to be productive areas. According to Lüning (1990), they may produce up to $1000 \mathrm{~g} \mathrm{C} \mathrm{m}^{-2} \mathrm{yr}^{-1}$.

In the present study, we combined data from a number of recently published studies and supplemented this with new data to compare the macrofauna composition on different types of macrophytes. One aim was to test similarities and dissimilarities in the fauna composition associated with macrophytes of different sizes, shapes and longevity, i.e. seagrass, fucoids, turf algae and kelp. Another aim was to analyse the functional importance of different macrophytes as habitats and carbon sources to associated fauna. These analyses should enable us to better understand regulatory processes responsible for the high persistence of macro- 
phyte communities on the Norwegian coast. The data used are from a number of field studies and manipulations, mesocosm studies and laboratory experiments.

\section{MATERIALS AND METHODS}

For identification of fauna associated with habitatforming macrophytes, we sampled whole or parts of plants with associated organisms in situ by SCUBA. Sampling took place along a coastline of more than $1000 \mathrm{~km}$, between 58 and $64^{\circ} \mathrm{N}$, and in 4 regions: Region 1, the Norwegian south coast between 58 and $59^{\circ} \mathrm{N}$; Region 2 , the west coast at about $60^{\circ} \mathrm{N}$; Region 3 , the west coast at about $63^{\circ} \mathrm{N}$; and Region 4 , at $64^{\circ} \mathrm{N}$. Table 1 lists the species of macrophytes we focused on and in which region they were sampled. Faunal data from Laminaria hyperborea (Christie et al. 2003), Zostera marina and Fucus serratus samples from 2000 (Fredriksen \& Christie 2003, Fredriksen et al. 2005) have been previously described. In the case of the large kelp L. hyperborea, we sampled holdfasts, stipes (with epiphytes) and laminas separately, because they represent different habitat structures. Smaller kelps
(Saccarina latissima) and fucoids were sampled individually, while turf algae and above-ground seagrasses were sampled by use of frames $(20 \times 20$ or $50 \times$ $50 \mathrm{~cm}$, see Fredriksen et al. 2005). Macrophytes were carefully sampled and enclosed in fine mesh cotton bags and sealed in situ. Habitat size was determined by measuring displacement volume or wet weight of the macrophytes ( $1 \mathrm{ml}$ displacement $=1 \mathrm{~g}$ wet weight). We then collected the fauna by washing and sieving (mesh size $250 \mu \mathrm{m}$ ). The number of animals were counted and identified to species or the lowest possible taxonomic level. By this method we collected a representative sample of mobile animals, while sessile animals were less represented and were not a focus of the analyses in the present study. Faunal densities are reported as number of individuals related to size or wet weight of the macrophyte, and also as numbers per $\mathrm{m}^{2}$ for those sampled in quadrates. For estimations of faunal densities on macrophytes where single plants were sampled, we estimated L. hyperborea, Ascophyllum nodosum (L.) Le Jol. and Sargassum muticum (Yendo) Fensholt to densities of 10 plants $\mathrm{m}^{-2}$, and Fucus spp. and Saccharina latissima to $25 \mathrm{~m}^{-2}$ (based on authors' unpubl. data). These estimates provide conservative

Table 1. Mean (SE) and total number of fauna species in the macrophyte samples. Each sample consists of 3 or 4 replicate macrophyte individuals or quadrates (see 'Materials and methods') except for Sargassum muticum, where only 1 plant has been sampled. An estimate of mean (SE) faunal density (total no. animals $\mathrm{m}^{-2}$ ) is given based on extrapolations described in 'Materials and methods'

\begin{tabular}{|c|c|c|c|c|c|c|}
\hline Macrophyte species & Site (region) & Year & Month & $\begin{array}{l}\text { Mean } \\
\text { number }\end{array}$ & $\begin{array}{c}\text { Total } \\
\text { number }\end{array}$ & $\begin{array}{c}\text { Mean fauna } \\
\text { density }\end{array}$ \\
\hline \multirow[t]{8}{*}{ Laminaria hyperborea } & Froan V3 (4) & 1993 & 8 & $88(1.0)$ & 103 & 621863 (113650) \\
\hline & Froan V2 (4) & 1993 & 8 & $72(5.3)$ & 107 & $24680(5030)$ \\
\hline & Froan V1 (4) & 1993 & 8 & $60(2.4)$ & 92 & $15320(4150)$ \\
\hline & Seterøy (3) & 1995 & 8 & $89(2.8)$ & 132 & $55500(9490)$ \\
\hline & Kvaløy (3) & 1995 & 8 & $84(3.8)$ & 106 & $84273(14741)$ \\
\hline & Kvaløy (3) & 1996 & 9 & $96(0)$ & 119 & 126596 (23656) \\
\hline & Bergen (2) & 1997 & 9 & $96(4.6)$ & 125 & 12783 (2123) \\
\hline & Arendal (1) & 1996 & 8 & $71(7.0)$ & 90 & $25700(205)$ \\
\hline Saccharina latissima & Arendal (1) & 1996 & 8 & $42(6.0)$ & 62 & 110725 (18125) \\
\hline \multirow{3}{*}{ Fucus serratus } & Arendal (1) & 1996 & 8 & $34(5.2)$ & 56 & $172450(96600)$ \\
\hline & Arendal (1) & 2000 & 9 & $37(7.4)$ & 51 & 33625 (11400) \\
\hline & Arendal (1) & 2000 & 9 & $60(5.3)$ & 86 & 378250 (129 475) \\
\hline Ascophyllum nodosum & Arendal (1) & 1996 & 8 & $30(3.7)$ & 50 & 34920 (14 370) \\
\hline Sargassum muticum & Arendal (1) & 1996 & 8 & - & 37 & 681580 \\
\hline Ceramium rubrum & Arendal (1) & 1996 & 8 & $24(1.7)$ & 44 & $115300(27450)$ \\
\hline Rhodomela confervoides & Arendal (1) & 1996 & 8 & $37(2.3)$ & 67 & 143475 (13500) \\
\hline Scagelia sp. & Arendal (1) & 1996 & 5 & $25(3.0)$ & 50 & $8475(3650)$ \\
\hline Spongomorpha sp. & Arendal (1) & 1996 & 5 & $17(2.4)$ & 35 & $8625(3650)$ \\
\hline \multirow[t]{3}{*}{ Zostera marina } & Arendal (1) & 1996 & 8 & $43(1.7)$ & 70 & $31012(1444)$ \\
\hline & Arendal (1) & 2000 & 9 & $72(9.7)$ & 110 & $12188(1164)$ \\
\hline & Arendal (1) & 2000 & 9 & $54(2.5)$ & 75 & $53832(5764)$ \\
\hline \multirow[t]{2}{*}{ Fucus vesiculosus } & Hopavåg (4) & 1998 & 8 & $23(2.4)$ & 33 & $21200(7133)$ \\
\hline & Hopavåg (4) & 1998 & 10 & 19 (2.9) & 27 & 19041 (7798) \\
\hline \multirow[t]{2}{*}{ Saccharina latissima } & Grimstad (1) & 2008 & 8 & $35(4.0)$ & 49 & $22750(6536)$ \\
\hline & Bergen (2) & 2008 & 8 & $48(8.3)$ & 64 & $75833(27122)$ \\
\hline \multirow[t]{2}{*}{ Mixed red turf algae } & Arendal (1) & 2005 & 8 & $24(1.5)$ & 35 & $23508(4275)$ \\
\hline & Arendal (1) & 2008 & 8 & $27(3.5)$ & 36 & $32083(13787)$ \\
\hline \multirow{2}{*}{ Mixed brown turf algae } & Hyllestad (2) & 2005 & 8 & $33(1.2)$ & 45 & 11617 (2193) \\
\hline & Bergen (2) & 2008 & 8 & $31(1.5)$ & 42 & $30108(6043)$ \\
\hline
\end{tabular}


data as we only recorded adult plants, not including juvenile understory vegetation and epiphytes.

Faunal mobility, colonisation rates, habitat preferences and habitat use were studied by use of artificial substrates exposed in situ for different time periods (hours to weeks) within and outside macrophyte beds (Kraufvelin et al. 2002, Norderhaug et al. 2002, 2007, Jørgensen \& Christie 2003, WaageNielsen et al. 2003, Christie et al. 2007). Different mimics and/or artificial substrates were used to imitate different algal structures (Christie et al. 2007). A small experiment with artificial substrate in a fjord overgrazed by sea urchins was performed to study colonization of fauna in an area completely cleared of sublittoral macrophytes (new data presented here from the Porsanger fjord). Trophic relationships were studied with feeding experiments of mesograsers in smaller aquarium tests (Norderhaug et al. 2003, Christie \& Kraufvelin 2004, Kraufvelin et al. 2006a). Food chain analyses were performed using data from gillnet fishing and analysis of fish stomach contents and stable carbon isotope ratios (Fredriksen 2003, Norderhaug et al. 2003, 2005). Experimental tests of the functional relationships between seaweeds and associated fauna were performed in large intertidal mesocosms (Bokn et al. 2003, Kraufvelin et al. $2006 \mathrm{~b})$; these focused on fauna composition related to effects of eutrophication. We also had the opportunity to test the effects of physical disturbance on macrophytes by field sampling in areas trawled by commercial kelp harvesting (Christie et al. 1998).

Multidimensional scaling (MDS) (Shepard 1962, Kruskal 1964a,b) followed by SIMPER was used to analyse differences in the faunal composition between samples. Ordinations and clusters were based on similarity matrices using the PRIMER 5.2.1 computer package (Clarke 1993). We used the Bray-Curtis similarity index (Bray \& Curtis 1957) and all data were logtransformed.

\section{RESULTS AND DISCUSSION}

\section{Animal abundance and habitat size}

Although there was variation between samples, there was a generally positive correlation between animal abundance and habitat size across all macrophyte species and regions. Fauna densities on kelps, fucoids, turf algae and seagrass are listed in Table 1. Except for a few seasonal algae occurring only in the spring, the samples were taken in late summer when fauna abun- dances peak (Christie et al. 2003). Variation in correlations between habitat size and animal abundances is probably partly due to the method used in calculating habitat volume, because the habitat does not only consist of the algal surface, but also the interstitial volume (Hacker \& Steneck 1990). Animal density per $100 \mathrm{~g}$ of 6 epiphytic red algae on kelp stipes (Table 2) was higher on complex than structurally simple algae. Palmaria palmata (L.) Kuntze, with smooth surfaces, housed lower densities than the structurally more complex Rhodomela sp. and Ptilota gunneri P.C. Silva, Maggs \& L.M. Irvine.

The highest macrofauna densities and largest habitat sizes were found in kelp forests in exposed coastal areas in mid-Norway: average fauna densities exceeded half a million animals per $\mathrm{m}^{2}$ (Stn Froan V3, Table 1). The highest number of animals found on a single kelp occurred on the largest of the 4 replicate kelps from Stn Froan V3, which housed about 90000 specimens. Kelp size and epiphyte volume increased with increasing wave exposure (Christie et al. 1998, 2003), which led to higher numbers of associated animals. At the Froan stations, which represent an exposure gradient, the kelp at the most exposed station, V3, was largest in size and had larger epiphytes (see Christie et al. 2003) and higher densities of animals than the moderately and less exposed Stns V2 and V1, respectively. Christie et al. (2003) also found a significant positive correlation between kelp size and fauna abundance within kelp plants sampled at the same site at Finnøy in Region 3, but no correlation between kelp size and number of associated animal species. To test the effect of habitat volume independently of macrophyte food value or differences in habitat complexity, we performed field experiments using uniform artificial habitat of different sizes (Norderhaug et al. 2007). We found that the faunal abundance increased with increasing habitat volume (Fig. 1). The increase in habitat size did not result in any significant increase in number of species. The increase in faunal abundance with increasing natural and artificial habitat size (volume) indicates that there is a strong need for habitats among the macrophyte fauna; the correlation between 


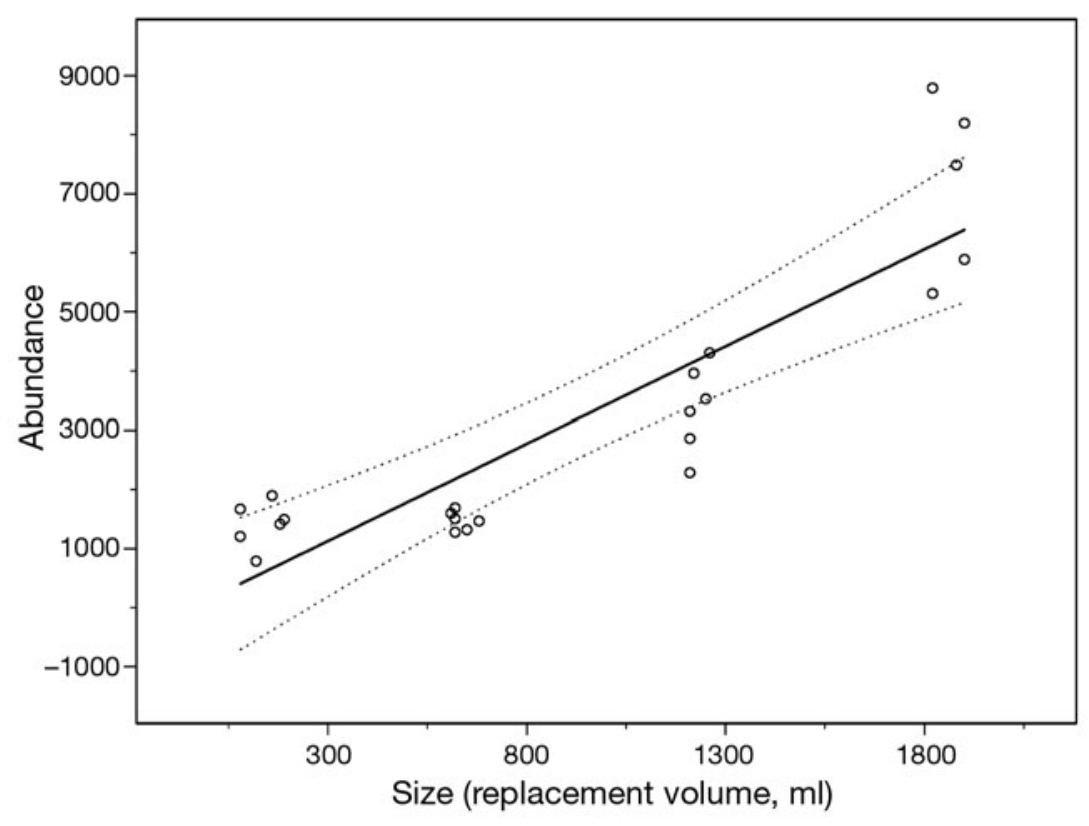

Fig. 1. Abundances (no. specimens) of mobile macrofauna in relation to habitat size (measured as replacement volume, $\mathrm{ml})( \pm 95 \% \mathrm{CI})$ sampled on different natural (epiphytic red algae) and artificial (rope bundles) habitats. The samples grouped to the left in the plot (i.e. the samples with the lowest size) are natural habitats. The larger samples are samples with natural habitat and respectively one, two or three additional rope bundles, each of $600 \mathrm{ml}$. Data from Norderhaug et al. (2007)

faunal abundance and artificial habitat volume particularly indicates that habitat (and not food) is a limited resource in these systems.

Many of the sampled macrophyte communities had densities of about 100000 animals $\mathrm{m}^{-2}$. The lowest faunal densities (and also lowest species richness) were found in ephemeral turf algae of small size and low habitat complexity. These turfs dominated protected areas after disappearance of sugar kelp in southern Norway (Moy et al. 2008). Low densities of animals in these turf samples may also be due to high grazing pressures by small fish, since Moy et al. (2008) observed very high densities of Labridae and Gobiidae. Faunal densities were also lower in intertidal algae (like Fucus vesiculosus) than in structurally similar submerged species. This is expected since the littoral zone is a physically harsher environment than the sublittoral zone.

\section{Animal diversity and habitat structure}

While animal abundances correlated with habitat size, species richness was dependent on habitat structure. More species were associated with algae of high structural complexity (Tables 1 \& 2; for further details see Christie et al. 2003, 2007). Further, the associated faunal composition seems to be dependent on macrophyte form or structurally similar species. A comparison of faunal composition on 9 species of macrophytes (Laminaria hyperborea separated into holdfast, stipes and lamina) sampled at the same area (see Table 1) showed similarity (grouping) of 3 replicate samples within each macrophyte species (or kelp part), while the different macrophytes are separated (Fig. 2). The SIMPER test revealed that the most common (and ubiquitous) faunal species to a great extent explained both similarities and differences between the associated faunal communities on the different macrophytes, indicating that these species are present on most macrophytes, but at different scales of abundance. A consistent, common pattern of dominance of crustaceans and molluscs was found. However, the different macrophytes housed different numbers of species (Table 1) as well as different species (see below). Structurally similar species such as kelps and fucoids housed a rich faunal community and many similar species (e.g. Rissoa parva da Costa). The Zostera marina samples were also species-rich and housed other species of gastropods and amphipods (see below [p. 237]) and some species which may be more related to soft bottom habitats. Many of the turf algae are structurally uniform and the associated faunal communities were species-poor.

Fig. 3 shows an MDS plot of fauna on Laminaria hyperborea holdfast, stipes and lamina sampled at the 4 different regions of the Norwegian coast. The faunal composition differed between the 3 different parts of the kelp. Laminas from Region 1 are positioned close to the stipes. These laminas were overgrown by epiphytic red algae similar to that which had overgrown the stipes, and were thus structurally similar to the stipes. The faunal composition from each kelp part was similar across all 4 regions. This shows that the physical structure of the habitat is a more important factor than latitude (gradual change in species composition; vertically in plot) for the faunal community structure. Norderhaug et al. (2002) distinguished between holdfast fauna, stipe fauna and ubiquitous fauna, and SIMPER analysis from the present study shows which species contributed most in distinguishing between lamina, stipes and holdfast faunal assemblages (horizontally in the plot). While gastropods such as Gibbula cineraria (L.), Ansates pellucida (L.) and Lacuna vincta 


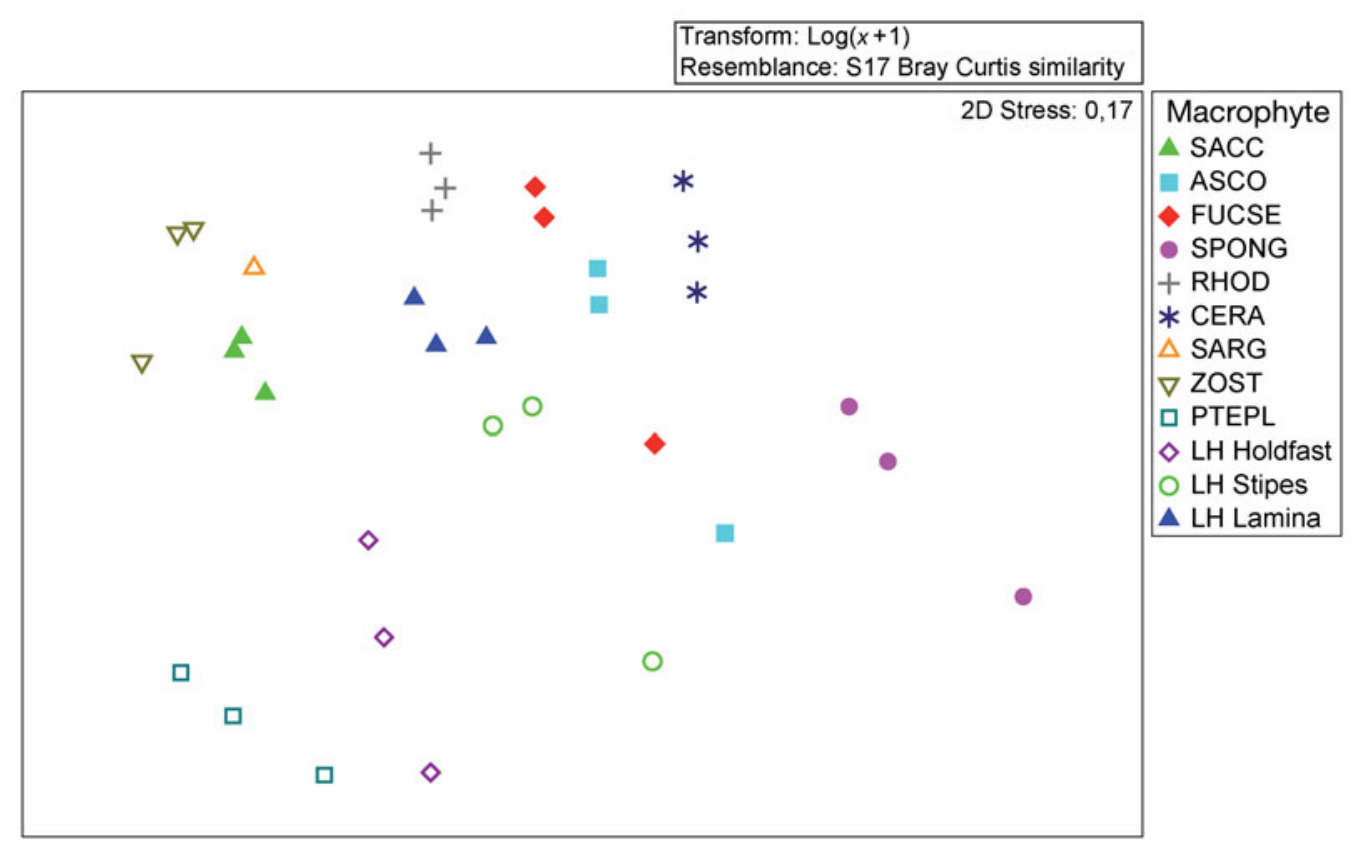

Fig. 2. Multidimensional scaling plot of fauna from 3 replicate samples of 10 different macrophytes sampled at Arendal in 1996. Differences in faunal composition between the macrophyte host species are shown. SACC: Saccharina latissima; ASCO: Ascophyllum nodosum; FUCSE: Fucus serratus; SPONG: Spongomorpha sp.; RHOD: Rhodomela confervoides; CERA: Ceramium rubrum; SARG; Sargassum muticum (only 1 sample); ZOST: Zostera marina; PTEPL: Pterothamnion plumula; LH: Laminaria hyperborea (holdfast, stipes, lamina separated)

(Montagu) dominated on the smooth lamina, mobile amphipods like Jassa falcata (Montagu), Apherusa jurinei (Milne-Edwards) and A. bispinosa (Bate) and rissoidae gastropods dominated the stipes, and more sedentary amphipods like Corophium bonelli (G.O. Sars) and burrowing polychaetes and mussels like Hiatella arctica (L.) dominated the holdfasts.
Sampling of individual epiphytic algae and comparisons with different mimics showed that the faunal composition differed between rough, bushy and smooth substrate regardless of whether the sample was algae or a mimic (Fig. 4; Christie et al. 2007). Also, samples of Zostera marina and Fucus serratus from different sites showed a high degree of similarity in epiphyte and

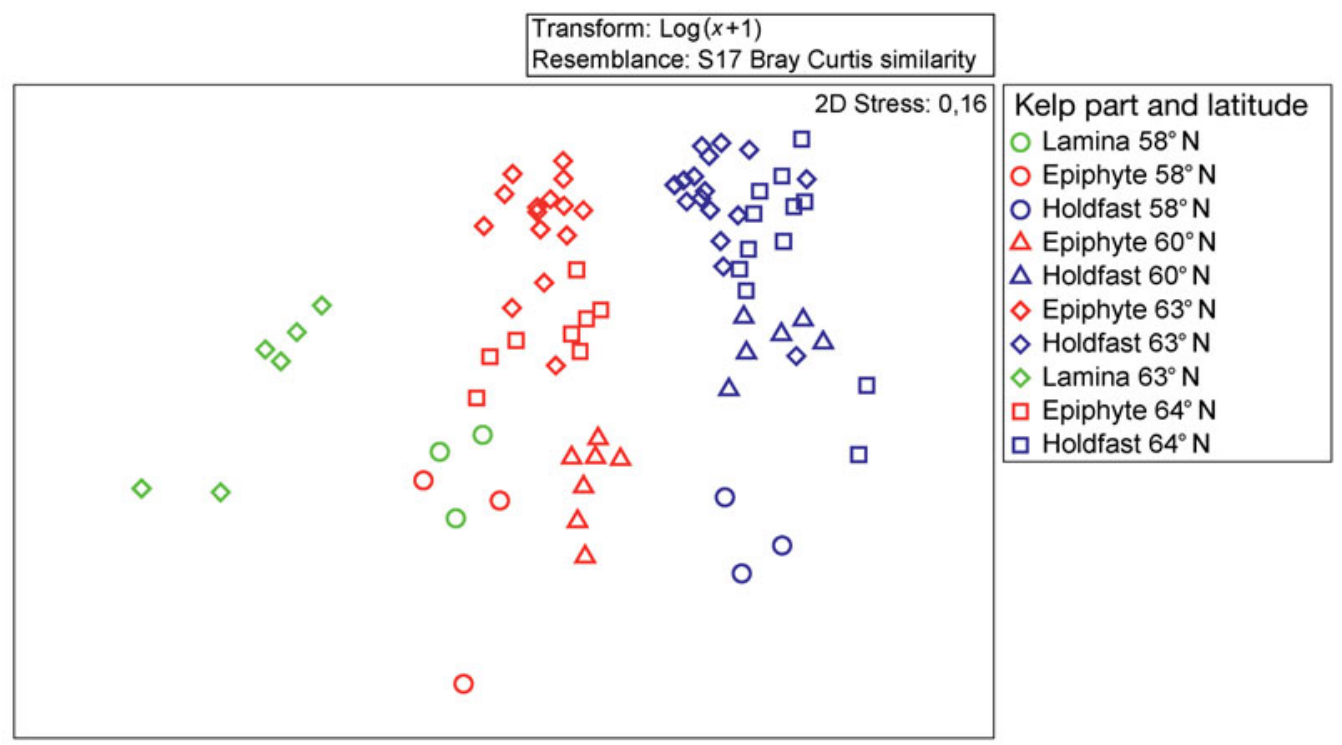

Fig. 3. Multidimensional scaling plot reflecting faunal composition on kelp lamina, holdfasts and epiphytic red algae on the kelp stipes from different regions on the Norwegian coast. Data from Christie et al. (2003) 


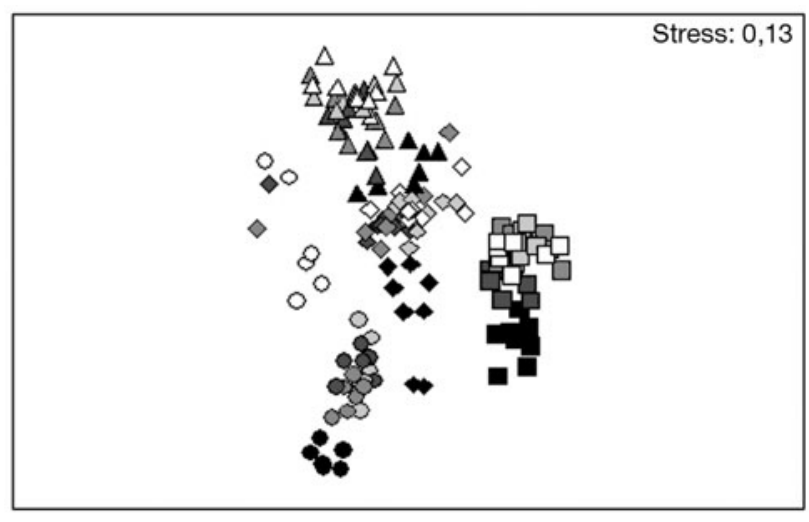

Fig. 4. Multidimensional scaling plot of faunal composition in kelp parts and mimics. Symbols indicate different substratescircles: kelp parts; squares: bushy mimics; diamonds: rough mimics; triangles: smooth mimics. For each substrate, filled black symbols indicate the bottom level, grey shading the middle level (lighter at higher positions), and unfilled symbols the top level. For the kelp plants, black is used for the holdfast, shading for stipe sections with epiphytes and white for the lamina. Data from Christie et al. (2007)

faunal content within macrophyte species (Fig. 5). Differences between associated organisms on these 2 macrophytes were clear even though they were sampled only a few meters apart at each station, and even though both macrophytes have relative smooth surfaces. More than 200 macrofaunal species have been identified in these 2 communities, and the density of animals was about 100000 individuals $\mathrm{m}^{-2}$ in both the fucoid and seagrass beds (Fredriksen et al. 2005). The differences in species composition are evidenced by the dominance of the gastropod Rissoa parva on F. serratus and $R$. membranacea (J. Adams) on Z. marina, while the closely related Ischyroceridean amphipods Jassa falcata (Montagu) and Erichtonius difformis (Milne Edwards) were similarly almost exclusively found at high abundances on F. serratus and Z. marina, respectively (see Fredriksen et al. 2005).

The data presented in Figs. 2 to 5 indicate that structural diversity is of great importance for the diversity of associated faunal species. In addition, Figs. 3 \& 4 illustrate differences in the vertical distribution of fauna on upright habitats; there are different faunal compositions from the canopy layer downwards to the substratum level (see also Christie et al. 2003, 2007). This may be due to differences in macrophyte structure and longevity of the habitat and also other factors (see 'Faunal mobility').

The number of faunal species found in the samples of 3 or 4 replicate Laminaria hyperborea kelps varied between 90 and 132, while average number of species found on single kelps was about 80 to 90 . By including fauna on 56 kelps (L. hyperborea), Christie et al. (2003)

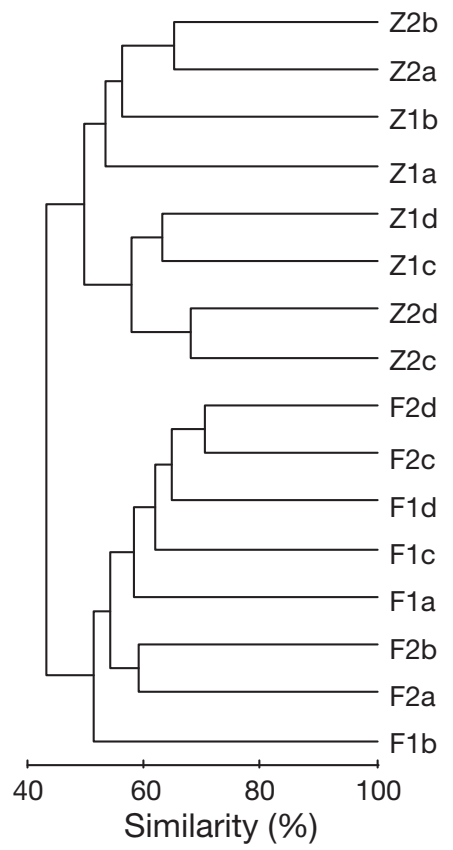

Fig. 5. Dendrogram comparing faunal composition in Zostera marina (Z) and Fucus serratus (F) at $3 \mathrm{~m}$ depth growing close to each other at 2 sites (1 and 2). Samples from April, June, September and November are indicated by a, b, c and d, respectively. Data from Fredriksen \& Christie (2003)

identified a total of 238 species. The most abundant and species-rich faunal group was amphipods, with 60 species, while 48 species were identified in the second most abundant group, gastropods. In all macrophytes, amphipods and other crustaceans, gastropods, bivalves and polychaetes dominated most samples, both in number of species and abundance (Christie et al. 2003, 2007, Fredriksen et al. 2005, present study; Table 1). Most of the animal species were small, typically $<10 \mathrm{~mm}$. Although abundances varied with habitat size, the number of associated faunal species did not. However, species number was higher in the large and more complex macrophytes such as kelps than in the smaller turf algae (Table 1).

The number of species of associated fauna was found to depend on habitat architecture (complexity) as described above. The large number of faunal species on less complex habitats such as Zostera marina and Fucus serratus (Table 1, see Fredriksen et al. 2005) may be due to factors that increase the habitat complexity. Fredriksen et al. (2005) found more than 100 species of small epiphytic algae on $Z$. marina and F. serratus; these algae contribute to the habitat volume and complexity and thereby to higher diversity of associated fauna. Some of the variation in faunal composition within the same macrophyte species (Table 1) is probably due to differences in epiphytic load. 


\section{Macrophytes as habitat and food}

Macrophytes in the present study were mainly used by fauna as habitat and were not grazed. As primary producers, macrophytes are among the most productive on the planet (Lüning 1990, Mann 2000, Barrón et al. 2003, Abdullah \& Fredriksen 2004) and may thus be expected to be important as a food resource to associated fauna. A food chain from macrophytes via invertebrates to fish has been identified (Norderhaug et al. 2003, Fredriksen 2003, Norderhaug et al. 2005); however, the macrophyte carbon is not grazed directly, probably due to a high C:N ratio in the summer (Norderhaug et al. 2003). Consequently, carbon is released as dissolved organic matter (DOM) or particulate organic matter (POM), degraded (and enriched) by microorganisms and then made available as food to animals. This is shown by Norderhaug et al. (2003) for POM, where common kelp faunal species did not survive or grow when fed fresh kelp, but only when fed kelp degraded (or enriched) by microorganisms. Further, Norderhaug (2004) showed that kelp-associated amphipods selected habitat (red algal species) according to architectural structure and complexity and not according to food value, indicating that the habitat was mainly important for protection and not as a food source (see also Paul et al. 2001). Normally, as the macrophytes are not grazed, but rather support the fauna with food after being released as POM or DOM and degraded, the macrophytes are prevented from being overgrazed by their inhabitants. Kelp and other macroalgae release a high percentage of their carbon production as DOM (Barrón et al. 2003, Abdullah \& Fredriksen 2004), and a proportion of this may form the mucus layer on algal surfaces that has been found to attract microorganisms (Gismervik 2004). This may be a nutrient source for, in particular, gastropods that are observed feeding on these surfaces; however, this must be further investigated.

Field data support the results discussed above. POM sampled in sediment traps in dense kelp forest showed a stable isotope ratio in the same range as kelp $(-16$ to $-18 \%$, Fredriksen 2003). The POM C:N ratio from sediment traps was lower than in kelp, indicating a higher nutritional value. Stomach analysis from kelp forest fish revealed that these fish species mainly fed on kelp fauna (Norderhaug et al. 2005) and stable isotope analysis also showed kelp-derived carbon to be important (Fredriksen 2003). The kelps are thus the primary producer supplying the kelp forest ecosystem with carbon, but the kelps are mainly eaten by mesograzers as degraded (or N-enriched) POM or DOM rather than being grazed.

The mesograzers feeding on macrophyte surfaces remove smaller epiphytes like diatoms and foliose algae, and are thus important for keeping the larger macrophytes free from being overgrown by epiphytic competitors (Moksnes et al. 2008). However, in some cases the grazers increase in density to an extent that they start to overgraze the macrophytes which are then grazed to extinction. This has been observed for kelp, although they are not preferred as food (see Christie \& Rueness 1998). The most extensive event in Norwegian waters is the grazing of kelp by sea urchins, resulting in a marine desert along almost half the coastline (Sivertsen 1997). Smaller grazers (mesograzers) like the gastropod Rissoa membranacea, which is common on seagrass in southern Norway, have also been found to graze down seagrass beds when occurring in high densities (Fredriksen et al. 2004). Grazer densities seem to be regulated by fish predation in healthy macrophyte systems (Moksnes et al. 2008), and by dispersal out of the system (Jørgensen \& Christie 2003, Christie \& Kraufvelin 2004). Thus, the macrophytes may become vulnerable if grazers occur in too high numbers; for example, disappearance of regulatory processes by overfishing of top predators has been suggested as a reason for blooms of sea urchins, leading to overgrazing and decimation of kelp beds (Steneck et al. 2004).

\section{Faunal mobility}

High faunal mobility ensures rapid colonization and utilization of available habitats. The most abundant faunal components associated with macrophytes are highly mobile. They move frequently between plants (Norderhaug et al. 2002) and there is high dispersal out of macrophyte beds (Jørgensen \& Christie 2003, Waage-Nielsen et al. 2003, Christie \& Kraufvelin 2004). Mobility and dispersal patterns have emerged by exposing artificial substrates for study of colonization over short periods (hours to weeks). Fig. 6 shows numbers of kelp fauna collected on substrates exposed within the kelp forest and at different distances into sandy bottom habitat over $4 \mathrm{~d}$. Waage-Nielsen et al. (2003) found rapid and abundant dispersal of kelp fauna to areas with no kelp. Most species dispersed rapidly and were found in high densities on artificial substrates inside and at different distances outside the kelp forest. High dispersal or export of mobile fauna from fucoid communities has also been documented in controlled mesocosm studies (Christie \& Kraufvelin 2004). Between 1 and $2 \%$ of the amphipod and isopod populations were lost from the mesocosms daily, while the populations and abundances still persisted throughout years (no dispersal into the mesocosms was observed).

There are, however, differences in the mobility of faunal species, and based on data comparing occur- 

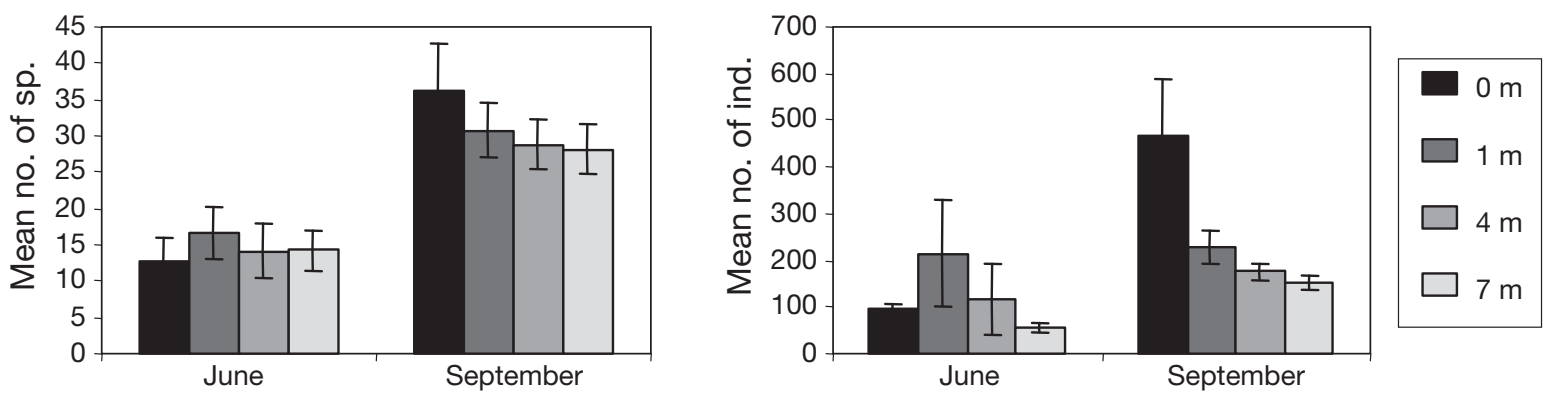

Fig. 6. Colonisation by kelp fauna of artificial substrate exposed for $4 \mathrm{~d}$ inside a kelp forest ( $0 \mathrm{~m})$ and at different distances $(1,4$ and $7 \mathrm{~m}$ ) from the kelp on a sandy bottom in June and September, presented as mean number of species and mean number of individuals per artificial substrate. Error bars are SE. Data from Jørgensen \& Christie (2003)

rences in natural habitats and artificial substrates exposed for short time periods (Norderhaug et al. 2002, Waage-Nielsen et al. 2003), the relative mobility of the different species groups was estimated. Amphipods and some other crustaceans had high relative mobility, as well as gastropods (by drifting, Vahl 1983, Christie et al. 2007). Other abundant faunal groups associated with macrophytes, such as polychaetes and bivalves, had lower relative mobilities. In the kelp forest, Norderhaug et al. (2002) found lower mobility among animals living in kelp holdfasts than animals living on epiphytes on the stipes. A high dispersal rate, even among gastropods and bivalves that are regarded as slow or sedentary, is most likely an adaptation to life associated with ephemeral habitats. As laminas and many epiphytic algae are annuals or of even shorter seasonal duration, animals need to move between available habitats to a greater extent than those living in the holdfast, which has a lifetime of $10 \mathrm{yr}$ or more. While high mobility increases the ability to colonise habitats, it is also expected to be disadvantageous by increasing the exposure to predators like fish, and increasing the risk of being transported out of the macrophyte bed. Jørgensen \& Christie (2003) found higher dispersal at night than during the day, probably to avoid visual predators like fish. High dispersal rates may also be a result of space limitation. Manipulations where artificial habitats of different sizes were anchored to kelp stipes showed correlations between faunal abundance and habitat size (see Fig. 1). Winder (1990) suggested that habitats can support more animals if the animals are in regular movement. Hence, the above mentioned studies indicate that space is limited.

\section{Disturbances and macrophyte persistence}

Disturbances in macrophyte systems may have great implications for the abundance and species composition of the associated fauna (see Table 1, Fig. 2). A number of disturbances, including anthropogenic activities, negatively affect macrophyte systems and in some cases bring the systems out of equilibrium (Steneck \& Carlton 2001). This may lead to a phase shift and a new stable state, but in other situations, stabilising mechanisms bring the system back towards its origin. Data from several studies have demonstrated both cases.

Storm events and kelp harvesting (kelp trawling, see Christie et al. 1998) are disturbances that have limited effect due to the high resilience of the kelp forest. Both storms (large wave actions) and kelp trawls remove the adult canopy plants, but an understory of kelp recruits respond to the removal of the canopy by increasing their growth rate, ensuring that kelp outcompetes other macrophytes (Christie et al. 1998). Kelp can grow to full canopy size in a few years, and harvesting in Norwegian waters is, depending on latitude, allowed every 4 or 5 yr. However, the kelp forest ecosystem has not fully recovered after $5 \mathrm{yr}$ and, although the mobile fauna have potential for quick recolonization to the new kelp, the stipe epiphytes and thus important habitats do not recover fully for 5 to $7 \mathrm{yr}$.

In Norwegian waters, overgrazing by the sea urchin Strongylocentrotus droebachiensis O.F. Müller has been the most extensive threat to macrophyte beds (Sivertsen 1997). A sea urchin bloom some 40 yr ago resulted in destructive grazing of large areas of kelp forests (see Sivertsen 1997, Norderhaug \& Christie 2009). The kelp forest system flipped to a new stable state (barren ground) that has persisted since then. The barren state will persist as long as the sea urchins can maintain their high population densities (see Norderhaug \& Christie 2009). A decrease in sea urchin abundance will lead to reestablishment of the kelp forest (Christie et al. 1995, Leinaas \& Christie 1996, Norderhaug \& Christie 2009). While the kelp forest is a habitat for a rich fauna (see Table 1), the barren ground is almost totally depleted of all plants and animals (except sea urchins), and a comparison of production has shown a difference of 2 orders of magnitude 
(Chapman 1981). We have performed similar studies of mobile fauna in kelp beds and on barren grounds by use of short-term artificial substrates. In kelp beds and adjacent to kelp beds, standardised rope bundles were colonized by an average of about 40 species and 500 individuals within 4 d (Fig. 6, see also Norderhaug et al. 2002, Waage-Nielsen et al. 2003) and during one night only, Jørgensen \& Christie (2003) found an average of 21 species (SE $=0.8$ ) and 178 (5.4) individuals dominated by amphipods and gastropods. In the large barren ground area in the Porsanger fjord, the average colonization to 15 rope bundles exposed for $1 \mathrm{~d}$ was only 4.7 (0.5) species and 52 (8.6) individuals (present study, August 2006). A majority of the colonizing animals were juvenile mussels and amphipods, probably dispersed from fucoids in the intertidal zone. This confirms the low faunal diversity and abundance in barren areas.

Shifts caused by eutrophication have been reported in a number of shallow benthic systems, where canopyforming perennial macroalgae and seagrasses have been replaced by ephemeral filamentous algae (e.g. Duarte 1995, Schramm 1996, Valiela et al. 1997, Worm \& Lotze 2006, Burkholder et al. 2007). Although these communities may be resistant to disturbances such as eutrophication, Bokn et al. (2003) reported no large effects on fucoid communities of nutrient additions during a 3-yr experimental mesocosm study. By prolonging the experiment performed by Bokn et al. (2003) for another $2 \mathrm{yr}$, Kraufvelin et al. (2006b) detected a sudden and dramatic shift from perennials to ephemerals (mainly Ulva spp.) in eutrophicated mesocosms, while the perennial communities persisted in the control mesocosms. After ending the experiment and terminating nutrient additions, the affected communities recovered within 1 to $2 \mathrm{yr}$. This shows that the system can be robust for a long period, showing no response to disturbance, but once a threshold is reached the community may flip to another state (delayed effects), and also show high resilience when the disturbance decreases. There may be similar mechanisms behind the dramatic Saccharina latissima decline in southern Norway, where large areas formerly covered by $S$. latissima have been replaced by turf algae communities (Moy et al. 2008). Synergetic effects including global warming, overfishing and eutrophication may be driving forces for this phase shift (Worm \& Lotze 2006, Jackson 2008). On the Swedish Skagerrak coast, Moksnes et al. (2008) found that reduced grazing by mesograzers on ephemeral algae increased the effects of eutrophication in seagrass beds. Cascading effects caused by overfishing of larger predatory fish resulted in increased stocks of small fish, reduced mezograzer populations (and activity) and increased growth of ephemeral algae. So far this has not been investigated on the Norwegian Skagerrak coast, but some data indicate a similar pattern (Moy et al. 2008). Coastal fish stocks including coastal cod stocks have been reduced (cod is on the Norwegian 'Red list'), and there has been a reduction in mesograzer abundance when macrophyte beds shift from perennial- to turf algae-dominated communities (Table 1).

\section{CONCLUSIONS}

Macrophyte habitats are highly productive systems which comprise rich associated faunal communities. They cover large areas of the Norwegian coast and provide habitat for macrofaunal communities, which typically exceed densities of 100000 individuals $\mathrm{m}^{-2}$. Habitat size was the most important factor in determining animal abundances, and small-scale structural complexity was the most important factor for the faunal diversity and composition; this trend was consistent over large areas. The macrofauna associated with macrophytes were generally highly mobile, and fauna associated with perennial habitats were typically less mobile than fauna associated with habitats of shorter duration. The species found in the kelp holdfasts, with longevity of $10 \mathrm{yr}$ and more, are less mobile than species living on seasonal algae (Norderhaug et al. 2002).

High mobility increases exposure to visual predators such as fish and increases dispersal (loss) out of the system, but it may still be advantageous for macrophyte-associated animals. High mobility increases the ability to utilize available habitat. Sampling and manipulations in macrophyte systems indicated that space (and not food) is limited for the mobile macrofauna, and high mobility may be an advantage where this resource is limited (Winder 1990, Norderhaug et al. 2002, 2007, Christie \& Kraufvelin 2004). Grazer control, as a factor contributing to the prevention of overgrazing, may be important for the persistence of the system.

A food chain structure has been found, where macrophyte POM - the kelp is not suitable food before it has been released as POM and degraded by bacteria (Norderhaug et al. 2003) - is used by invertebrates, which in turn are eaten by fish (Fredriksen 2003, Norderhaug et al. 2005) and also lost from the system by export. Habitat availability seems important in regulating mesograzer abundances. The result is an ecosystem with high persistence where the invertebrates are prevented from overgrazing their habitat. If the grazer control for some reason is removed, grazer populations may increase and overgrazing may occur.

Thus, the macrophyte system seems to be persistent due to a balance of regulatory mechanisms between 
primary producers, grazers and/or herbivores and predators. The diversity of macrophyte species in terms of architecture (structural complexity) is, according to the data presented here, important for the diversity of associated invertebrates. The diversity of the macrophytes seems to be dependent on a balanced distribution and grazing activity among the grazers, which prefer different macrophytes (Duffy et al. 2001, 2003). A high functional redundancy will further increase the stability of the macrophyte system. If the grazer populations decline then the perennial macrophytes may be overgrown by filamentous algae (see Moksnes et al. 2008), resulting in decreasing diversity of algae and animals (Table 1). The last example has been described as a cascade (top-down) effect caused by overfishing of predatory fish and enhanced by other (synergetic) factors (see Jackson et al. 2001, Jackson 2008).

A growing awareness of the importance of macrophyte beds as habitats and producers for species-rich and abundant fauna has increased the focus on these systems. They are now regarded as an important part of the coastal ecosystem by nature and resource management authorities in Norway. As the persistence, resilience and vulnerability of these systems are dependent on interactions between large macrophytes, smaller epiphytes, grazers and animals higher up in the food web, knowledge of ecosystem structure and function is necessary for decision-making regarding kelp trawling-, fishery- and eutrophication-related management. Future research should, in particular, focus on the possible effects of overfishing in coastal areas.

\section{LITERATURE CITED}

Abdullah MI, Fredriksen S (2004) Production, respiration and exudation of dissolved organic matter by the kelp Laminaria hyperborea along the west coast of Norway. J Mar Biol Assoc UK 84:887-894

Baden SP, Boström C (2000) The leaf canopy of seagrass beds: faunal community structure and function in a salinity gradient along the Swedish coast. In: Reise K (ed) Ecological comparisons of sedimentary shores. Ecological Studies 151, Springer-Verlag, Berlin, p 213-236

Baden SP, Phil L (1984) Abundance, biomass and production of mobile fauna in Zostera marina (L.) meadows, western Sweden. Ophelia 23:65-90

> Barrón C, Marbà N, Duarte CM, Pedersen MF and others (2003) High organic carbon export precludes eutrophication responses in experimental rocky shore communities. Ecosystems 6:144-153

Bokn TL, Duarte CM, Pedersen MF, Marba N and others (2003) The response of experimental rocky shore communities to nutrient additions. Ecosystems 6:577-594

Bray JR, Curtis JT (1957) An ordination of the upland forest communities of southern Wisconsin. Ecol Monogr 27: 325-349

Burkholder JA, Tomasko DA, Touchette BW (2007) Sea- grasses and eutrophication. J Exp Mar Biol Ecol 350:46-72 Chapman ARO (1981) Stability of sea urchin dominated barren grounds following destructive grazing of kelps in St. Margaret's Bay, eastern Canada. Mar Biol 62:307-311

Christie H, Kraufvelin P (2004) Mechanisms regulating amphipod population density within macroalgal communities with restricted predator impact. Sci Mar 68:189-198

Christie H, Rueness J (1998) Tareskog (kelp forests). In: Rinde E, Bjørge A, Eggereide A, Tufteland G (eds) Kystøkologi, den ressursrike norskekysten. Universitetsforlaget, Oslo, p 164-189

Christie H, Leinaas HP, Skadsheim A (1995) Local patterns in mortality of the green sea urchin, Strongylocentrotus droebachiensis, at the Norwegian coast. In: Skjoldal HR, Hopkins C, Erikstad KE, Leinaas HP (eds) Ecology of fjords and coastal waters. Elsevier, Amsterdam, p 573-584

Christie H, Fredriksen S, Rinde E (1998) Regrowth of kelp and colonization of epiphyte and fauna community after kelp trawling at the coast of Norway. Hydrobiologia 375376:49-58

Christie H, Jørgensen NM, Norderhaug KM, Waage-Nielsen E (2003) Species distribution and habitat exploitation of fauna associated with kelp (Laminaria hyperborea) along the Norwegian coast. J Mar Biol Assoc UK 83:687-699

Christie H, Jørgensen NM, Norderhaug KM (2007) Bushy or smooth, high or low; importance of habitat architecture and vertical position for distribution of fauna on kelp. J Sea Res 58:198-208

Clarke KR (1993) Non-parametric multivariate analyses of changes in community structure. Aust J Ecol 18:117-143

Colman J (1940) On the faunas inhabiting intertidal seaweeds. J Mar Biol Assoc UK 24:129-183

Dommasnes A (1969) On the fauna of Corallina officinalis L. in western Norway. Sarsia 38:71-86

Duarte CM (1995) Submerged aquatic vegetation in relation to different nutrient regimes. Ophelia 41:87-112

Duffy JE, Macdonald KS, Rhode JM, Parker JD (2001) Grazer diversity, functional redundancy, and productivity in seagrass beds: an experimental test. Ecology 82:2417-2434

> Duffy JE, Richardson JP, Canuel EA (2003) Grazer diversity effects on ecosystem functioning in seagrass beds. Ecol Lett 6:637-645

Edgar GJ (1990) The influence of plant structure on the species richness, biomass and secondary production of macrofaunal assemblages associated with Western Australian seagrass beds. J Exp Mar Biol Ecol 137:215-240

- Edgar GJ (1991) Artificial algae as habitats for mobile epifauna: factors affecting colonization in a Japanese Sargassum bed. Hydrobiologia 226:111-118

Edwards A (1980) Ecological studies of the kelp, Laminaria hyperborea, and its associated fauna in south-west Ireland. Ophelia 19:47-60

- Elner RW, Vadas RL Sr (1990) Inference in ecology: the sea urchin phenomenon in the Northwestern Atlantic. Am Nat 136:108-125

- Fenwick GD (1976) The effect of wave exposure on the amphipod fauna of the algae Caulerpa browni. J Exp Mar Biol Ecol 25:1-18

$>$ Fredriksen S (2003) Food web studies in a Norwegian kelp forest based on stable isotope $\left(\delta^{13} \mathrm{C}\right.$ and $\left.\delta^{15} \mathrm{~N}\right)$ analysis. Mar Ecol Prog Ser 260:71-81

Fredriksen S, Christie H (2003) Zostera marina (Angiospermae) and Fucus serratus (Phaeophyceae) as habitat for flora and fauna: seasonal and local variation. In: Chapman ARO, Anderson RJ, Vreeland VJ, Davison IR (eds) Proc 17th Int Seaweed Symp, Cape Town, 28 Jan-2 Feb 2001. Oxford University Press, Oxford, p 357-364 
Fredriksen S, Christie H, Bostrom C (2004) Deterioration of eelgrass (Zostera marina L.) through destructive grazing by the gastropod Rissoa membranacea (J. Adams). Sarsia 89:218-222

Fredriksen S, Christie H, Sætre BA (2005) Species richness in macroalgae and macrofauna assemblages on Fucus serratus L. (Phaeophyceae) and Zostera marina L. (Angiospermae) in Skagerrak, Norway. Mar Biol Res 1:2-19

Gismervik I (2004) Podite carrying ciliates dominate the benthic ciliate community in the kelp forest. Aquat Microb Ecol 36:305-310

- Hacker SD, Steneck RS (1990) Habitat architecture and the abundance and body-size-dependent habitat selection of a phytal amphipod. Ecology 71:2269-2285

Hagerman L (1966) The macro and microfauna associated with Fucus serratus L. with some ecological remarks. Ophelia 3:1-43

> Jackson JBC (2008) Ecological extinction and evolution in the brave new ocean. Proc Natl Acad Sci USA 105: 11458-11465

> Jackson JBC, Kirby MX, Berger WH, Bjorndal KA and others (2001) Historical overfishing and the recent collapse of coastal ecosystems. Science 293:629-638

> Jones DJ (1971) Ecological studies on macroinvertebrate populations associated with polluted kelp forests in the North Sea. Helgol Wiss Meeresunters 22:417-441

Jorde I (1966) Algal associations of a coastal area south of Bergen, Norway. Sarsia 23:1-52

> Jørgensen NM, Christie H (2003) Diurnal, horizontal and vertical dispersal of kelp-associated fauna. Hydrobiologia 503:69-76

Kraufvelin P, Christie H, Olsen M (2002) Macrofauna (secondary) responses to experimental nutrient addition to rocky shore mesocosms and a coastal lagoon. Hydrobiologia 484:149-166

Kraufvelin P, Salovius S, Christie H, Moy FE, Karez R, Pedersen MF (2006a) Eutrophication-induced changes in benthic algae affect the behaviour and fitness of the marine amphipod Gammarus locusta. Aquat Bot 84:199-209

Kraufvelin P, Moy FE, Christie H, Bokn TL (2006b) Nutrient addition to experimental rocky shore communities revisited: delayed responses, rapid recovery. Ecosystems 9: 1076-1093

Kruskal JB (1964a) Multidimensional scaling by optimizing goodness-of-fit to a nonmetric hypothesis. Psychometrika 29:1-28

Kruskal JB (1964b) Nonmetric multidimensional scaling: a numerical method. Psychometrika 29:115-129

Lawrence JM (1975) On the relationship between marine plants and sea urchins. Oceanogr Mar Biol Annu Rev 13: 213-286

> Leinaas HP, Christie H (1996) Effects of removing sea urchins (Strongylocentrotus droebachiensis): stability of the barren state and succession of kelp forest recovery in the east atlantic. Oecologia 105:524-536

Lüning K (1990) Seaweeds: their environment, biogeography, and ecophysiology. John Wiley \& Sons, New York

Mann KH (2000) Ecology of coastal waters: with implications for management. 2nd edition. Blackwell Science, Malden, MA

Marstein AC (1997) Epiphytic algae on kelp stipes from Vega - an area with varying densities of sea urchins. Blyttia 55:123-129 (In Norwegian with English Abstract)

> Martin-Smith KM (1993) Abundance of mobile epifauna: the role of habitat complexity and predation by fishes. J Exp Mar Biol Ecol 174:243-260

Moksnes PO, Gullstrom M, Tryman K, Baden S (2008) Trophic cascades in a temperate seagrass community. Oikos 117 : 763-777

Moore PG (1973) The kelp fauna of northeast Britain. II. Multivariate classification: turbidity as an ecological factor. J Exp Mar Biol Ecol 13:127-163

Moore PG (1986) Levels of heterogeneity and the amphipod fauna of kelp holdfasts. In: Moore PG, Seed R (eds) The ecology of rocky coasts. Colombia University Press, New York, p 274-290

Moy F, Christie H, Steen H, Stålnacke P and others (2008) Final report from the sugar kelp project. SFT-rapport TA-2467/2008, NIVA-rapport 5709, NIVA, Oslo (in Norwegian)

Nelson WG (1980) A comparative study of amphipods in seagrasses from Florida to Nova Scotia. Bull Mar Sci 30:80-89

> Norderhaug KM (2004) Use of red algae as hosts by kelpassociated amphipods. Mar Biol 144:225-230

Norderhaug KM, Christie H (in press) Sea urchin grazing and kelp re-vegetation in the NE Atlantic. Mar Biol Res

> Norderhaug KM, Christie H, Rinde E (2002) Colonisation of kelp imitations by epiphyte and holdfast fauna; a study of mobility patterns. Mar Biol 141:965-973

> Norderhaug KM, Fredriksen S, Nygaard K (2003) Trophic importance of Laminaria hyperborea to kelp forest consumers and the importance of bacterial degradation to food quality. Mar Ecol Prog Ser 255:135-144

Norderhaug KM, Christie H, Fosså JH, Fredriksen S (2005) Fish-macrofauna interactions in a kelp (Laminaria hyperborea) forest. J Mar Biol Assoc UK 85:1279-1286

Norderhaug KM, Christie H, Fredriksen S (2007) Space limitation in a Norwegian kelp Laminaria hyperborea forest? Evidence from using artificial habitats. J Sea Res 58: $120-124$

Paul VJ, Cruz-Rivera E, Thacker RW (2001) Chemical mediation of macroalgal-herbivore interactions: ecological and evolutionary perspectives. In: McClintock JB. Baker BJ (eds) Marine chemical ecology. CRC Press, Boca Raton, FL, p 227-265

Pinnerup SP (1980) Leaf production of Zostera marina L. at different salinities. Ophelia Suppl 1:219-224

Schramm W (1996) The Baltic Sea and its transition zones. In: Schramm W, Nienhuis PH (eds) Marine benthic vegetation. Recent changes and effects of eutrophication. Springer, Heidelberg, p 131-163

Schultze K, Janke K, Krüß A, Weidemann W (1990) The macrofauna and macroflora associated with Laminaria digitata and L. hyperborea at the island of Helgoland (German Bight, North Sea). Helgol Mar Res 44:39-51

Shepard RN (1962) The analysis of proximities: multidimensional scaling with an unknown distance function. II. Psychometrika 27:219-246

Sivertsen K (1997) Geographical and environmental factors affecting the distribution of kelp beds and barren grounds and changes in biota associated with kelp reduction at sites along the Norwegian coast. Can J Fish Aquat Sci 54:2872-2887

Sjøtun K, Fredriksen S, Rueness J, Lein TE (1995) Ecological studies of the kelp Laminaria hyperborea (Gunnerus) Foslie in Norway. In: Skjoldal HR, Hopkins C, Erikstad KE Leinaas HP (eds) Ecology of fjords and coastal waters. Elsevier, Amsterdam, p 525-536.

Steneck RS, Carlton JT (2001) Human alterations of marine communities: Students beware. in: Bertness MD, Gaines SD, Hay ME (eds) Marine community ecology. Sinauer Associates, Sunderland, MA, p 445-468

Steneck RS, Graham MH, Bourque BJ, Corbett D, Erlandson JM, Estes JA, Tegner MJ (2002) Kelp forest ecosystems: 
biodiversity, stability, resilience and future. Environ Conserv 29:436-459

Steneck RS, Vavrinec J, Leland AV (2004) Accelerating trophic-level dysfunction in kelp forest ecosystems of the Western North Atlantic. Ecosystems 7:323-332

Vahl O (1983) Mucus drifting in the limpet Helcion (=Patina) pellucida (Prosobranchia, Patellidae). Sarsia 68:209-211

Valiela I, McClelland J, Hauxwell J, Behr PJ, Hersh D, Foreman K (1997) Macroalgal blooms in shallow estuaries: controls and ecophysiological and ecosystem conse-

Submitted: May 6, 2009; Accepted: September 30, 2009 quences. Limnol Oceanogr 42:1105-1111

> Waage-Nielsen E, Christie H, Rinde E (2003) Short term dispersal of kelp fauna to cleared (kelp harvested) areas. Hydrobiologia 503:77-91

- Winder L (1990) Predation of ceral aphid Sitobion avenae by polyphagous predators on the ground. Ecol Entomol 15: 105-110

Worm B, Lotze HK (2006) Effects of eutrophication, grazing, and algal blooms on rocky shores. Limnol Oceanogr 51: 569-579

Proofs received from author(s): November 27, 2009 